\title{
EN 1090 i jej wymagania \\ w zakresie zabezpieczenia antykorozyjnego stalowych konstrukcji spawanych
}

\author{
Standard EN 1090 and its requirements \\ for corrosion protection of welding steel constructions
}

\section{Streszczenie}

W referacie przedstawiono wymagania PN-EN 1090 oraz norm przez nią przywołanych, w zakresie zabezpieczenia antykorozyjnego stalowych konstrukcji spawanych. W szczególności wymagania odniesiono do specyfikacji i projektu konstrukcji, wyposażenia produkcyjnego i kontrolnego oraz kwalifikacji personelu. Zwrócono uwagę na konieczność właściwego opracowania specyfikacji wyrobu przez projektujących konstrukcję jak również przeglądu wymagań dokonywanego przez wytwórców. Stopień spełnienia wymagań zobrazowano na podstawie doświadczeń autora $z$ audytowania systemów ZKP wg EN 1090-1. Referat, zwraca również uwagę na bezwzględną konieczność spełnienia wymagań w zakresie kwalifikacji i kompetencji personelu antykorozji.

Słowa kluczowe: specyfikacja elementu, EN 1090, zabezpieczenie antykorozyjne

\begin{abstract}
The paper presents the requirements of EN 1090 and referred standards in scope of corrosion protection of welding steel constructions . In particular, the requirements referred to the technical specification and design of the structure, production equipment, quality control equipment and personnel qualifications. Attention was drawn to the need for proper development of technical specifications of the product by designer as well as the review of the requirements made by the manufacturers. The degree of compliance is illustrated based on the author's experience with auditing systems according to EN 1090-1 FPC. The paper, also draws attention to the absolute necessity to meet the requirements for the qualifications and competence of corrosion protection personnel.
\end{abstract}

Keywords: component specification, EN 1090, corrosion protection

\section{Wstęp}

Spełnienie wymagań zharmonizowanej normy EN 10901[1] „Wykonanie konstrukcji stalowych i aluminiowych. Zasady oceny zgodności elementów konstrukcyjnych" oraz norm przez nią przywołanych, jest warunkiem niezbędnym do oznakowania konstrukcji budowlanej znakiem CE, a co za tym idzie możliwością wprowadzenia konstrukcji na rynek.

Wymagania techniczne wykonania konstrukcji stalowych zawarte są w części drugiej EN 1090-2[2] „Wykonanie konstrukcji stalowych i aluminiowych. Wymagania techniczne dotyczące konstrukcji stalowych". Wymagania dla konstrukcji aluminiowych zawiera część trzecia EN 1090-3[3].

Przywołane normy obejmują swym zakresem między innymi przygotowanie powierzchni i wykonanie zabezpieczenia antykorozyjnego konstrukcji poprzez malowanie, cynkowanie, natryskiwanie cieplne.

Niniejsze opracowanie odnosi się tylko do niektórych zagadnień z zakresu antykorozji i ma na celu zwrócenie uwagi na ważność procesów projektowania i wykonania konstrukcji, na późniejszy efekt jakościowy zabezpieczenia antykorozyjnego. Uwzględnia również konieczność zapewnienia odpowiednio kwalifikowanego i kompetentnego personelu w tym zakresie.

\section{Zabezpieczenie antykorozyjne wg EN 1090}

Zabezpieczenie antykorozyjne stalowych konstrukcji budowlanych to niezmiernie ważny element ich trwałości i niezawodnej eksploatacji.

Trwałość - należy w tym wypadku rozumieć, jako przydatności konstrukcji dla określonego lub długiego czasu użytkowania, bez utraty właściwości użytkowych lub jej osłabienia przy założonych w projekcie warunkach eksploatacji. Trwałość elementu zależy od jego zastosowania, warunków ekspozycji i wszystkich, zastosowanych środków ochrony przed korozją.

PN-EN 1090 Wykonanie konstrukcji stalowych i aluminiowych w swej pierwszej części „Zasady oceny zgodności elementów konstrukcyjnych" [1], w punkcie 4 dotyczącym

Mgr inż. Jerzy Kozłowski - SLV-GSI Polska Sp. z o.o.

Autor korespondencyjny/Corresponding author: jurek_kozlowski@op.pl 
wymagań dla elementów konstrukcji, odnosząc się do trwałości nakazuje, by wszystkie wymagania dotyczące zabezpieczenia przed korozją określone zostały w specyfikacji elementu.

W zakresie metod mających na celu wykazanie zgodności norma podaje "nie ma bezpośredniej metody badania trwałości. Ocenia się ją pośrednio, sprawdzając wymagania dotyczące zabezpieczenia powierzchni podane w specyfikacji elementu z warunkami jego eksploatacji.

PN-EN 1090 [1,2] stała się podstawą do powiązania zależności między trwałością wyrobu, a zastosowanym zabezpieczeniem antykorozyjnym. W części 2 dotyczącej wymagań technicznych, w rozdziale 10 określa wymagania dotyczące przygotowania powierzchni elementów do nakładania powłok malarskich lub innych, po wytworzeniu elementu konstrukcji. Przywołuje również konieczność uwzględnienia w specyfikacji wyrobu wymogów dotyczących zastosowania konkretnego systemu powłok antykorozyjnych.

W zakresie szczegółowych wymagań dotyczących systemów ochrony antykorozyjnej odsyła nas do:

- załącznika „F" EN 1090-2 [2] oraz EN ISO 12944 [4] w zakresie malowania powierzchni;

- załącznika „F" EN 1090-2 [2] oraz EN 14616 [5], EN 1531 [6], EN ISO 14713 [7] - w zakresie powłok metalowych natryskiwanych cieplnie;

- załącznika „F" EN 1090-2 [2] oraz PN-EN ISO 1461[8], EN ISO 14713 [7] - w zakresie cynkowania zanurzeniowego; Dla przygotowania powierzchni stalowych do nakładania powłok EN 1090-2 [2] wskazuje na wymagania EN ISO 85013 [9] oraz podkreśla, że wymagany stopień przygotowania powinien być również określony w specyfikacji elementu. W przypadku, gdy w specyfikacji nie określono inaczej, to dla klas wykonania konstrukcji EXC2, EXC3, EXC4 wystarczającym stopniem przygotowania jest stopień P1. Gdy określono oczekiwaną trwałość powłoki oraz kategorię korozyjności środowiska, wówczas stopień przygotowania należy przyjąć zgodnie z tablicą 22 (tab. I). Tabela przedstawia powiązanie stopnia przygotowania powierzchni z oczekiwaną trwałością powłok i kategorią korozyjności środowiska.

Tablica I. Stopień przygotowania powierzchni Table I. Degree of surface preparation

\begin{tabular}{|c|c|c|}
\hline $\begin{array}{c}\text { Oczekiwana } \\
\text { trwałość } \\
\text { powłok }^{\text {a }}\end{array}$ & $\begin{array}{c}\text { Kategoria } \\
\text { korozyjności }^{b}\end{array}$ & $\begin{array}{c}\text { Stopień } \\
\text { przygotowania }^{c}\end{array}$ \\
\hline \multirow{2}{*}{ powyżej 15 lat } & C1/C2 & P1 \\
\cline { 2 - 3 } & Powyżej C2 & P2 \\
\hline \multirow{2}{*}{ od 5 do 15 lat } & C1 do C3 & P1 \\
\cline { 2 - 3 } & Powyżej C3 & P2 \\
\hline \multirow{2}{*}{ powyżej 5 lat } & C1 do C4 & P1 \\
\cline { 2 - 3 } & C5 - Im & P2 \\
\hline
\end{tabular}

ab Oczekiwane trwałości powłok i kategorie korozyjności podano w kontekście NE ISO 12944 i EN ISO 14713

'Stopnień przygotowania P3 wymagany jest w szczególnych przypadkach

W przywołanej EN ISO 8501-3 [9] w sposób tabelaryczny ujęto rodzaje wad wraz $z$ ich ilustracjami i odniesieniem dla poszczególnych stopni przygotowania (P1, P2, P3). W wymaganiach EN 1090-2[2] p. 10 znajdujemy również zalecenia antykorozyjne w stosunku do:

- stali trudnordzewiejących;

- procedury zapewniających wizualną akceptowalność pokrytej rdzą powierzchni stali trudnordzewiejącej,
- zabezpieczenie przed zanieczyszczeniami olejem, smarem itp.

- korozji kontaktowej;

- w przypadku niezamierzonego styku wyrobów z różnych metali (np. stal nierdzewna i stal konstrukcyjna),

- w przypadku spawania stali nierdzewnej ze stalą konstrukcyjna - konieczności zachodzenia powłoki ochronnej (nie mniej niż 20mm) licząc od brzegu spoiny

- cynkowania zanurzeniowego;

- uszczelnienie wąskich szczelin w złączach spawanych przed dostępem kwasu,

- wykonanie otworów wentylacyjnych i odpływowych

- uszczelniania;

- określenie w specyfikacji sposobu zabezpieczenia powierzchni wewnętrznych,

- dopuszczalność stosowania spoin nieciągłych,

- powierzchni styku z betonem;

- zapewnienie powłoki ochronnej na szerokości co najmniej $50 \mathrm{~mm}$ od styku podstaw,

- oczyszczenie powierzchni niezabezpieczanych

- powierzchni niedostępnych;

- powierzchnie styku w połączeniach ciernych w celu uzyskania odpowiedniego współczynnika tarcia

- powłoki gruntujące i podkładowe w stykach i pod podkładkami,

- napraw po cięciu i spawaniu;

- zabezpieczenie miejsc gdzie usunięta lub zniszczona została powłoka cynkowa,

- czyszczenia powierzchni po montażu;

- czyszczenie elementów cienkościennych,

- czyszczenie elementów ze stali nierdzewnych.

Załącznik „F" do EN 1090-2[2] zawiera między innymi wymagania dla:

- specyfikacji eksploatacyjnej i technologicznej,

- warunków prowadzenia prac antykorozyjnych,

- przygotowania powierzchni elementów ze stali węglowej,

- powierzchni w trefach złączy spawanych,

- powierzchni w połączeniach sprężanych,

- przygotowania łączników,

- systemów powłok ochronnych,

- kontroli i oceny wykonanych powłok.

Należy bezwzględnie pamiętać, że zabezpieczenie antykorozyjne konstrukcji powstaje na wszystkich etapach wytwarzania, począwszy od opracowania i/lub przeglądu dostarczonej specyfikacji poprzez etapy projektowania, wytwarzania, nakładania zabezpieczenia antykorozyjnego, a na montażu kończąc.

Dlatego też jest niezmiernie ważnym, by personel odpowiadający za poszczególne etapy wytwarzania, posiadał niezbędną wiedzę również z zakresu antykorozji.

\section{Specyfikacja wyrobu}

Specyfikacja projektowa - wymagania dotyczące wyrobu (konstrukcji) wyspecyfikowane przez odbiorców lub przez organizację, z uwzględnieniem wymagań odbiorcy, lub wymagania przepisów.

Specyfikacja wykonawcza - zestaw dokumentów zawierających dane techniczne i wymagania dotyczące określonej konstrukcji stalowej/ aluminiowej łącznie z wymaganiami dodatkowymi i dotyczącymi zastosowania reguł EN 1090-2/-3 [2,3].

Załącznik A do EN 1090-1[1] opisuje dwa podstawowe przypadki opracowania specyfikacji: przez zamawiającego i przez producenta. Dość często specyfikację opracowuje zamawiający razem z wytwórcą. Podział pracy w tym zakresie jest umowny i powinien być sprecyzowany na etapie zamówienia lub umowy. 
W opracowanej specyfikacji powinny znaleźć się wszystkie techniczne informacje niezbędne do jego wyprodukowania łącznie z zabezpieczeniem antykorozyjnym.

Przewodnikiem do opracowania specyfikacji powinny być przedstawione w EN 1090-2 [2] tabele: A1 „Wykaz wymaganych informacji dodatkowych" oraz A1 "Wykaz opcji”.

W zakresie zabezpieczenia korozyjnego należy się odnieść między innymi do:

- rodzaju zabezpieczenia konstrukcji,

- systemu powłok ochronnych,

- stopnia przygotowania powierzchni lub oczekiwanej trwałości powłok w odniesieniu do korozyjności środowiska,

- wymagań technologicznych dla powłok,

- wymagań związanych z procedurą kwalifikacyjną procesu cynkowania ogniowego elementów profilowanych na zimno,

- niezbędnych powierzchni referencyjnych.

W specyfikacjach dla zabezpieczenia antykorozyjnego należy uwzględnić, w zależności od zastosowanego zabezpieczenia, wymagania norm EN ISO 12944-1\%8[4], EN ISO 14616[5], EN 15311[6], EN ISO 1461[8], EN ISO 14713[7].

Ze względu na fakt, że produkcja elementów powinna być prowadzona i kontrolowana z użyciem specyfikacji podającej wszystkie niezbędne informacje, z odpowiednimi szczegółami umożliwiającymi wytworzenie elementu i ocenę jego zgodności. Specyfikacja staje się jednym z najważniejszych dokumentów w procesie wytworzenia wyrobu. By jej opracowanie było właściwe, niezbędnym elementem jest posiadanie kompetentnego personelu w zakresie wszystkich stosowanych w procesie wytwarzania procesów, w tym również antykorozji.

\section{Projektowanie konstrukcji, a zabezpieczenie antykorozyjne}

Bez właściwego projektu nie jest możliwe skuteczne zabezpieczenie antykorozyjne konstrukcji. Projekt powinien zapewniać, że konstrukcja jest odpowiednia dla wyznaczonej jej funkcji, ma wymaganą stabilność, wytrzymałość i trwałość oraz akceptowalny koszt wytworzenia i zadowalający pod względem estetycznym wygląd. Powinien być sporządzony tak, aby umożliwiał właściwe przygotowanie powierzchni, nałożenie powłok, nadzór nad eksploatacją i renowację po założonym czasie użytkowania.

By etap projektowania konstrukcji był skuteczny pod względem zabezpieczenia antykorozyjnego, potrzebne jest spełnienie kilku warunków:

- koniecznym jest opracowanie wymagań dotyczących konstrukcji: wymagany okres ochrony; kategoria korozyjności środowiska, w którym konstrukcja będzie eksploatowana. $\mathrm{Na}$ ich podstawie należy określić wymagania odpowiednie dla mającego mieć zastosowanie rodzaju zabezpieczenia antykorozyjnego: przygotowanie powierzchni, wymagany system zabezpieczeń, liczba i rodzaj powłok, grubości powłok, metody nakładania, miejsce wykonywania prac antykorozyjnych (wytwórnia, budowa), wymagania dotyczące renowacji, wymagania dotyczące ochrony zdrowia, bezpieczeństwa pracy i ochrony środowiska.

- w przypadku opracowania specyfikacji wyrobu przez zamawiającego, wytwórca już na etapie przeglądu zamówienia lub umowy powinien dokonać analizy możliwości spełnienia wymagań dotyczących zabezpieczenia antykorozyjnego. Na tym etapie należy bezwzględnie ustalić jakie wymagania zawarł zamawiający np. „pomalować dwuwarstwowo w kolorze RAL..., grubość powłok minimum $260 \mu \mathrm{m}^{\prime \prime}$.
- jeśli projektant nie posiada odpowiedniej wiedzy z zakresu antykorozji to już w początkowym etapie projektowania powinien mieć możliwość konsultacji ze specjalistą w zakresie antykorozji.

Rzeczywistość spotykana podczas audytów to specyfikacje bardzo ograniczone w zakresie wymagań dla zabezpieczenia antykorozyjnego lub niezawierające odniesień do antykorozji. Często wymaganiem w specyfikacji jest tylko grubość powłoki malarskiej, jej kolor i okres wymaganej gwarancji. To wytwórca we własnym zakresie decyduje o pozostałych wymaganiach, nie znając nawet kategorii korozyjności środowiska, w którym konstrukcja będzie eksploatowana.

Specyfikacje nie podają wymagań, co do zastosowanych systemów malarskich wg EN ISO 12944-5 [4], nie odnoszą się do korozyjności środowiska, w którym konstrukcja będzie zamontowana. Wymagania gwarancyjne ograniczają się do podania tylko okresu gwarancji bez odniesień do ilości i rozmiaru uszkodzeń oraz dopuszczalnych zmian w wyglądzie powłok po czasie użytkowania (EN ISO 4628[10]). Zapomina się również o konieczności dokonywania okresowych przeglądów technicznych w czasie trwania gwarancji.

Brak kompetentnego, w zakresie antykorozji, personelu skutkuje projektami, w których nie uwzględnia się np. konieczności unikania ciasnych przestrzeni i zachowania minimalnych odległości pozwalających na właściwe przygotowanie powierzchni i ułożenie warstw antykorozyjnych, (rys. 1).
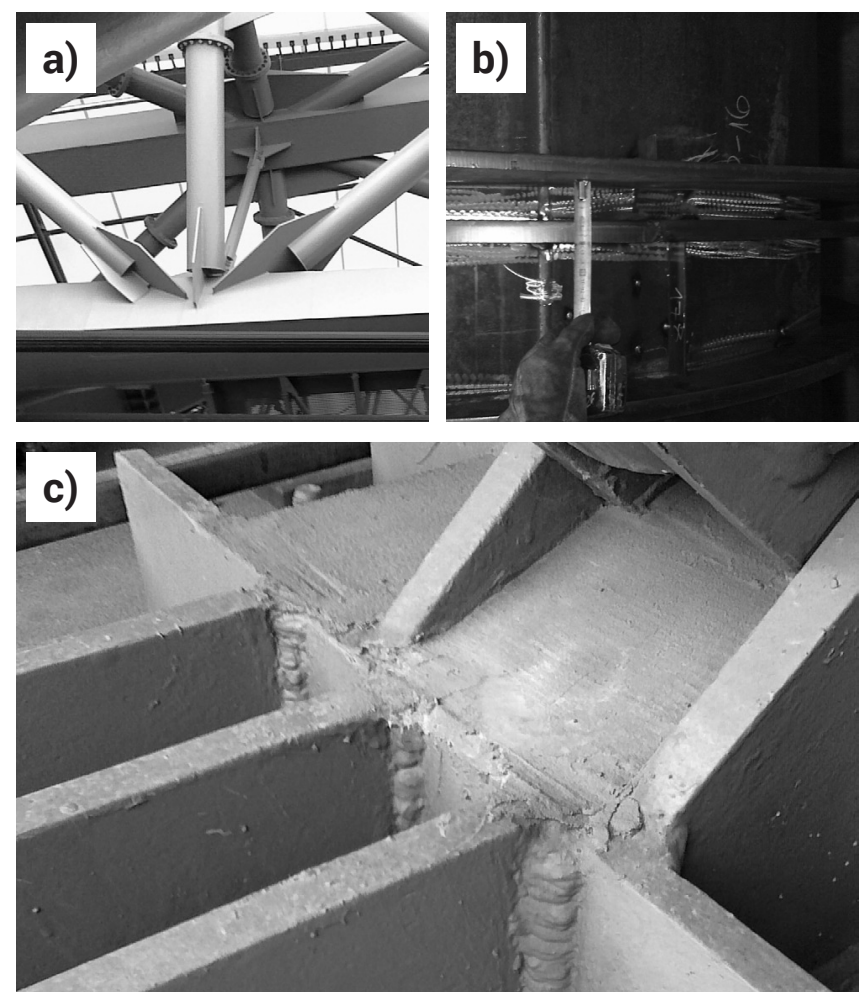

Rys. 1. a, b, c) brak zachowania minimalnych wymiarów

Fig. 1. a, b, c) lack of assure minimum dimension

W przypadku konstrukcji przeznaczonych do ocynkowania ogniowego, koniecznym jest spełnienie wymagań ISO 1461[8] i ISO 14713 [7]. W elementach zawierających przestrzenie zamknięte należy przewidzieć otwory odpowietrzające i odpływowe. Jest to szczególnie ważne dla uniknięcia ryzyka eksplozji w trakcie cynkowania hermetycznie zaspawanych elementów. Niestety często zdarza się, że $w$ dokumentacji znajduje się tylko zapis o cynkowaniu ogniowym i konieczności wykonania otworów technologicznych bez konkretnego ich umieszczenia w dokumentacji rysunkowej konstrukcji. Wytwórca natomiast nie zawsze 
jest w stanie właściwie zinterpretować te wymagania. Efektem braku przestrzegania zasad wykonania konstrukcji z uwzględnieniem cynkowania ogniowego są przedstawione na rysunku 3 a) rozerwanie i b) obszar niedocynkowany - spowodowane brakiem otworów technologicznych, c) „krwawy wyciek" z wąskiej szczeliny, niezamkniętej podczas spawania.

W przypadku zastosowania stali w nieodpowiedniej klasie przydatności do cynkowania ogniowego otzymujemy często nieakceptowalne przez zamawiającego przebarwienia powierzchni ocynkowanej (rys. 2a). Niezachowanie własciwej technologi przeróbki na zimno może skutkować wystąpieniem pęknięć podczas procesy cynkowania (rys. 2b).To tylko niektóre przykłady braku dostatecznej wiedzy personelu zaangażowanego w proces projektowania i wytwarzania konstrukcji.
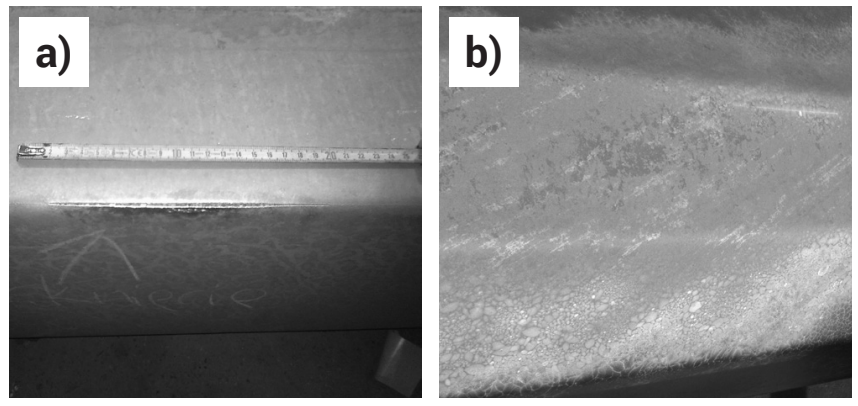

Rys. 2. a) pęknięcie podczas cynkowania ogniowego; b) „przebarwienia” Fig. 2. a) craks during hot-dip galvanizing ; b) "discoloration”
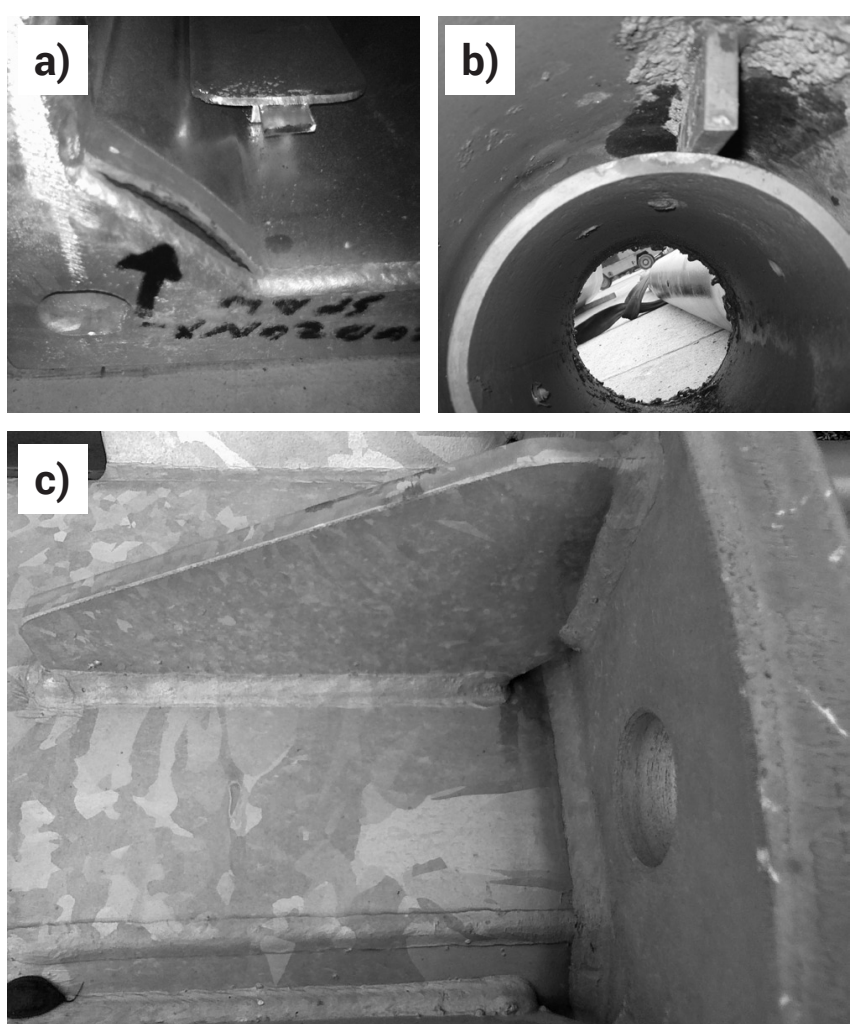

Rys. 3. a) rozerwanie b) niedocynk c) "krwawe wycieki”

Fig. 3. a) burst b) lack of galvanized coating c) "blood spills"

\section{Wyposażenie i infrastruktura}

\section{Wyposażenie do produkcji i kontroli}

Wymagania w odniesieniu do wyposażenia stosowanego przez wytwórcę w procesie produkcji oraz sprzętu wykorzystywanego do pomiarów i badań znajdujemy w EN 1090-1[1] w punkcie 6.3.3. „Wyposażenie stosowane w procesie produkcji powinno być regularnie kontrolowane i utrzymywane w stanie zapewniającym, że jego stosowanie nie spowoduje znaczących niezgodności w procesie produkcji". Podobne wymogi nadzoru obowiązują dla wyposażenia do pomiarów i badań, mającego wpływ na ocenę zgodności wyrobu. Sprzęt powinien być sprawdzany i kalibrowany w ustalonych odstępach czasu, według ustalonych procedur. Wymaga się przechowywania, przez okres określony w systemie FPC, dokumentów i zapisów potwierdzających prowadzenie takiego nadzoru.

Wymagania powyższe dotyczą wyposażenia stosowanego w procesie produkcji tzn. również wyposażenia stosowanego w procesie antykorozji.

Stopień spełnienia przytoczonych wymagań jest bardzo różny i zależy od poziomu wiedzy dotyczącej koniczności spełniania wymagań.

Funkcjonują organizacje, które posiadają i wykorzystują wyposażenia, a w zakresie "nadzoru” dokonują tylko niezbędnych bieżących napraw. W razie koniecznej potrzeby uzupełniają posiadane wyposażenie poprzez zakup.

W zakresie wyposażenia do kontroli procesu antykorozji najczęściej posiadany sprzęt ten to tylko termometr, wilgotnościomierz, przyrząd do pomiaru grubości na sucho, grzebień do pomiaru grubości na mokro, rzadziej folie kalibracyjne. Należy tu wspomnieć, że nie zawsze personel potrafi właściwie posługiwać się posiadanym wyposażeniem.

Wraz z rozwojem świadomości w zakresie systemów ZKP, rozszerza się również grupa wytwórców prowadzących pełen nadzór nad wyposażeniem. Posiadają oni opracowany i wdrożony system przeglądów wyposażenia produkcyjnego. Sprzęt do kontroli i badań jest regularnie sprawdzany w uprawnionych jednostkach zewnętrznych lub prowadzone są sprawdzenia własne na bazie posiadanych wzorców. Wyposażenie jest jednoznacznie zidentyfikowane wraz z przypisanym mu statusem kontroli i badań. Postępowanie takie jest pełnym spełnieniem wymagań sytemu FPC. $\mathrm{Na}$ podstawie doświadczenia audytowego można stwierdzić, że wraz ze wzrostem kwalifikacji i kompetencji kluczowego personelu tym właściwsze i lepiej nadzorowane wyposażenie. Przykłady pokazano na rysunku 4.
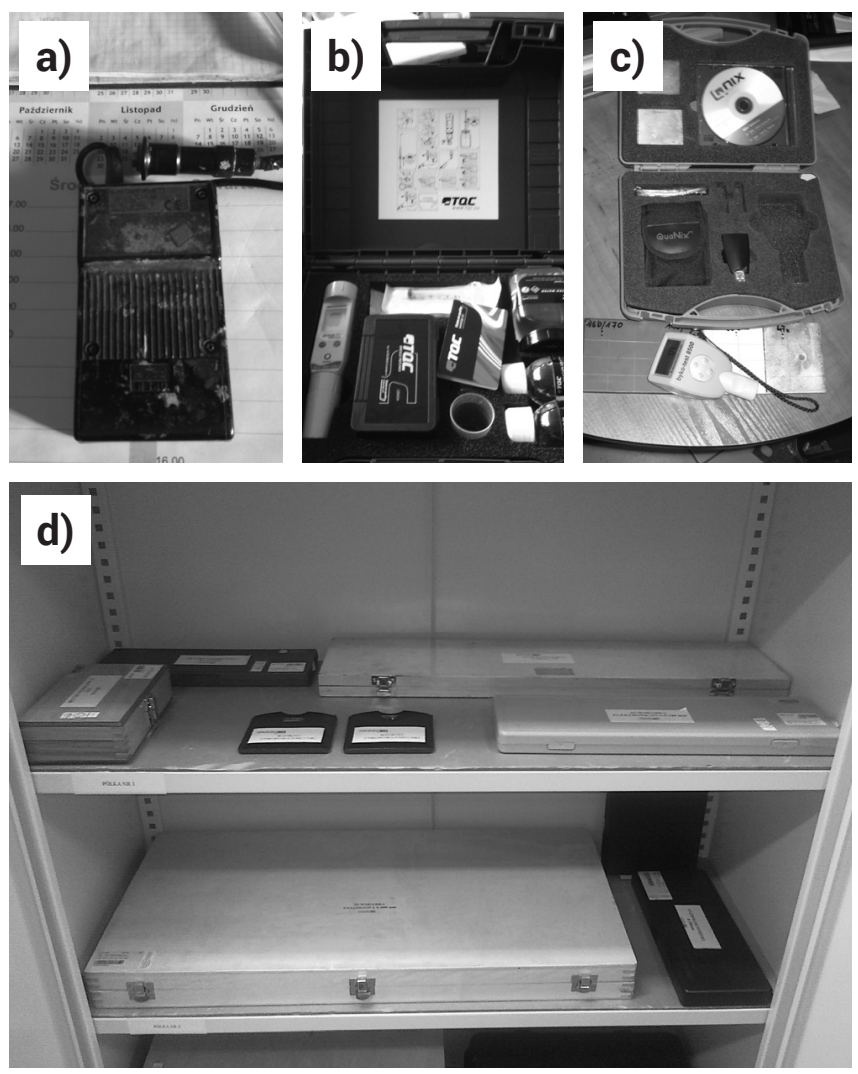

Rys. 4. Przykłady nadzorowania wyposażenia

Fig. 4. Examples of equipment supervision 


\section{Magazyny wyrobów lakierniczych}

W zależności od organizacji i skali prowadzonego procesu nakładania powłok antykorozyjnych wielkość i rodzaj pomieszczeń przeznaczonych do przechowywania materiałów lakierniczych jest oczywiście różna. Sposób przechowania to pełna rozbieżność od osobnych pomieszczeń z automatycznym nadzorowaniem i monitorowaniem warunków środowiskowych (rys. 5a) do składowania w „akurat wolnym zakątku hali produkcyjnej" (rys. 5b). Tu również kluczową rolę odgrywa świadomość personelu nadzorującego proces antykorozji.
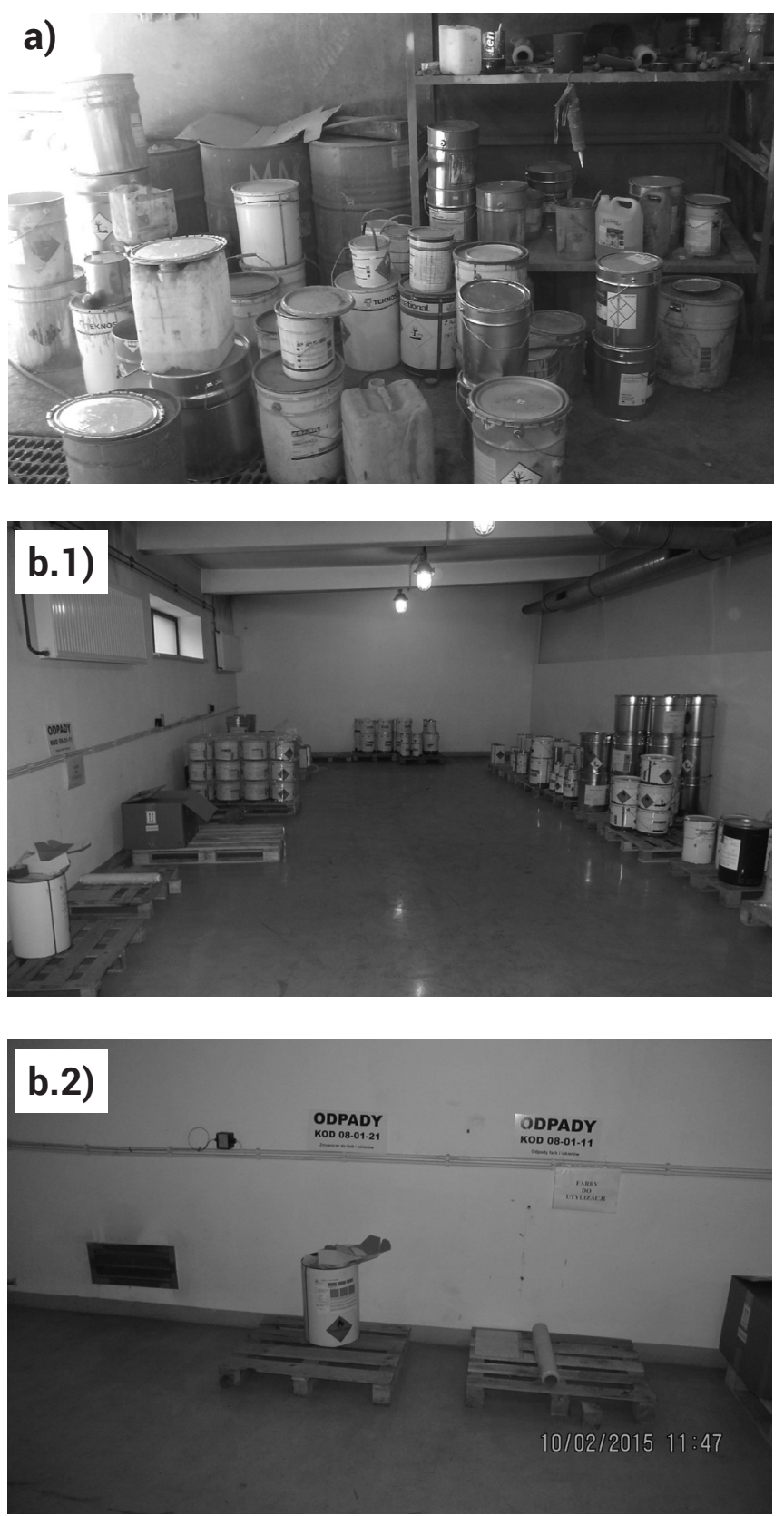

Rys. 5. Przykład przechowywania farb a) w dowolnym miejscu; b) magazyn

Fig. 5. An example of storage the paints a) anywhere, b) warehouse

\section{Pomieszczenia obróbki i czyszczenia oraz malarni}

Coraz częściej wytwórcy inwestują w profesjonalne komory do czyszczenia strumieniowo-ściernego, kabiny lakiernicze lub hale przystosowane do prac malarskich.

Niestety nierzadkie są też przypadki, że malowanie odbywa się w nieogrzewanych pomieszczeniach, gdzie nie ma możliwości dotrzymywania warunków środowiskowych. Oczywiście ma to bezpośrednie przełożenie na jakość wykonywanych powłok antykorozyjnych.

\section{Personel}

Zgodnie z wymaganiami normy EN 1090-1[1] odpowiedzialność, zwierzchność i wzajemne relacje personelu zarządzającego wykonywaniem prac mających wpływ na zgodność wyrobu, powinny być określone. Personel zaangażowany w działania mające wpływ na ocenę zgodności elementów powinien mieć odpowiednie kwalifikacje i być szkolony w zakresie elementów klasy wykonania egzekwowanej przez klienta. Wymagania te dotyczą również personelu zaangażowanego w wykonanie, nadzór i kontrolę wykonanych powłok zabezpieczeń antykorozyjnych.

W przypadku podzlecania usług antykorozyjnych koniecznym jest uwzględnienie zapisu normy EN ISO 12944-7 [4], "Firmy zawierające umowy na nakładanie ochronnych systemów malarskich na konstrukcje stalowe, i ich personel, powinny być zdolne do wykonania tych prac w sposób prawidłowy i bezpieczny. Prace wymagające szczególnej staranności powinny być wykonywane jedynie przez personel mający kwalifikacje potwierdzone przez upoważnioną instytucję, pod warunkiem, że strony nie uzgodniły inaczej”. „Powinno nadzorować się wykonanie pracy na wszystkich jej etapach. Nadzór powinny przeprowadzać odpowiednio wykwalifikowane i doświadczone osoby".

Niestety, często te wymagania są bagatelizowane. Zapomina się, że tylko kompetentny personel, posiadający wiedzę i doświadczenie w zakresie antykorozji, jest w stanie zapewnić właściwe wykonanie i ocenę jakości, zgodnie z warunkami zawartymi w specyfikacji wyrobu. Brak kompetentnego personelu potrafiącego przetransponować zapisy specyfikacji na wymogi dotyczące poszczególnych etapów procesu np. przygotowania powierzchni, sprawdzenia powierzchni choćby na obecność kurzu, zatłuszczeń, zanieczyszczeń jonowych itp. Świadomość kończy się na potrzebie wyczyszczenia konstrukcji, często bez odpowiedniego sprawdzenia stopnia tego wyczyszczenia; sprawdzeniu temperatury i wilgotności podczas malowania, ale bez odniesienia do temperatury punktu rosy i bez pomiaru temperatury malowanego elementu; nałożeniu warstw, bez przestrzegania wymaganego czasu schnięcia międzywarstw; pomiarze grubości całkowitej bez uwzględnienia wartości korygującej wynikającej z profilu powierzchni i ocenie wizualnej w skali „ładny/brzydki”. Prowadzenie zapisów z procesu traktowane jest, jako „zło konieczne".

Funkcjonują oczywiście organizacje, posiadające kompetentny personel, który we właściwy sposób prowadzi i nadzoruje prace antykorozyjne.

Aby mówić o prawidłowym funkcjonowaniu systemu ZKP wg EN 1090-1 [1], w organizacja musi mieć świadomość ważności wymagań i konieczności wykonywania zabezpieczenia antykorozyjnego zgodnie z wymaganiami ustalonymi w specyfikacji wyrobu, normie EN 1090-2[2] oraz w normach przez nią przywołanych.

W wielu przypadkach to dopiero podczas audytów ZKP wg EN 1090-1 [1] wytwórcy dowiadują się o wymaganych kompetencjach personelu antykorozji i o konieczności jego kształcenia. Nader często kształcenie pozostaje na poziomie krótkiego, kilkugodzinnego szkolenia, przeprowadzonego przez przedstawiciela wytwórcy farb. Szkolenia te w dużej części poświęcone są prezentacji wyrobów lakierniczych niż przekazywaniem wiedzy z antykorozji. Spotykane są również kilkugodzinne szkolenia dla personelu nadzoru prac antykorozyjnych, zakończone nawet „egzaminem”. Szkolenia takie dają poza wystawionym świadectwem, tylko złudzenie pełnego zapoznania się z procesem antykorozji.

Oczywiście mamy i dobre wzorce szkoleń. Wiedzę inspektora antykorozji można zdobyć min. na cieszącym się dużym uznaniem, 3 stopniowym kursie „Projektowanie i nadzór 
nad wykonywaniem zabezpieczeń antykorozyjnych na konstrukcjach stalowych" prowadzonym przez Instytut Badawczy Dróg i Mostów. IBDiM organizuje jeden cykl kursu rocznie. W mniejszym, na chwilę obecną, zakresie dostępne są kursy prowadzone np. przez norweskie FROSIO, niestety kursy te nie są prowadzone w języku polskim. Wychodząc naprzeciw potrzebom rynku, SLV-GSI Polska prowadzi działania mające skutkować uruchomieniem szkoleń FROSIO w języku polskim.

Ważnym problemem na rynku stalowych konstrukcji budowlanych jest brak obligatoryjnych wymagań dla wytwórców konstrukcji dotyczących posiadania kompetentnego personelu o określonym poziomie wykształcenia antykorozyjnego.

Działaniem w kierunku ujednolicenia wymagań jest realizowany w okresie 01.08.2013 - 31.07.2015, projekt partnerski „Porozumienie w zakresie dokształcania oraz transferu wiedzy w obszarze ochrony przed korozją - KorrAll” finansowany przez Komisję Europejską, w ramach programu „Uczenie się przez całe życie"- Leonardo da Vinci. Program ma na celu nawiązanie współpracy w zakresie szkolenia zawodowego dla obszaru zabezpieczeń antykorozyjnych. Uczestnikami - partnerami programu są:

- Uniwersytet „Eftimie Murgu” z Resita (Rumunia),

- Rumuńskie Stowarzyszenie Spawalnicze (Asociatia de Sudura din Romania),

- SLV-GSI Polska Sp. z o.o.,

- IFINKOR- Instytut przy Wyższej Szkole Zawodowej Południowej Westfalii (Niemcy), zaś jednostką wiodącą (koordynatorem) jest GSI SLV Duisburg (Niemcy).

$\mathrm{Na}$ ile wyniki tego programu przybliżą nas do ujednolicenia wymagań, pokaże przyszłość.

\section{Podsumowanie i wnioski}

Powyższe opracowanie odnosi się tylko do niektórych zagadnień związanych z problemem zabezpieczenia antykorozyjnego spawanych konstrukcji stalowych. Wystawiając deklarację właściwości użytkowych i oznakowując konstrukcję znakiem CE wytwórca potwierdza, że w procesie wytwórczym przestrzegano wymagań zawartych w PN-EN 1090 oraz normach przez nią przywołanych. Niedopuszczalnym staje się więc pominięcie wymagań dotyczących zabezpieczenia antykorozyjnego w specyfikacji wyrobu. Wszystkie cechy wyrobu, również te dotyczące antykorozji muszą być określone i zadeklarowane w sposób świadomy i z zachowaniem nakazanych wymagań.

Niezmiernie często spotykane jest pobieżne traktowanie tematu zabezpieczenia antykorozyjnego konstrukcji zarówno w wymaganiach stawianych przez zamawiających jak również w samych projektach konstrukcji. Spotykane zapisy - „konstrukcje należy cynkować” czy „konstrukcję pomalować na kolor RAL..., grubość całkowita minimum $180 \mu \mathrm{m}$ " to przecież tylko lakoniczne stwierdzenia wskazujące wprost, że ich autorom brak wiedzy w zakresie zabezpieczenia antykorozyjnego.

Wprowadzający na rynek, wystawiając deklarację właściwości użytkowych i oznakowując konstrukcję znakiem CE musi mieć pełną świadomość ważności deklarowanych cech wyrobu.

Wejście w życie Rozporządzenia 305/2011 oraz zharmonizowanej normy 1090-1 [1] wprowadziło obowiązek znakowania wyrobów budowlanych znakiem CE, przed ich wprowadzeniem na rynek. Obowiązek ten dotyczy również stalowych i aluminiowych konstrukcji budowlanych.

Deklarowanie trwałości wyrobu, a co za tym idzie, właściwości jego zabezpieczenia antykorozyjnego się obowiązkiem producenta (wprowadzającego na rynek).

Opracowywana specyfikacja wyrobu musi obejmować również aspekt jego zabezpieczenia antykorozyjnego.

Skuteczności procesów projektowania, wytwarzania i zabezpieczenia antykorozyjnego zależy bezpośrednio od kompetencji personelu biorącego udział w procesie.

Należy zwrócić szczególna uwagę na kwalifikacje i kompetencje, w zakresie antykorozji, osób odpowiedzialnych za projektowanie, opracowywanie specyfikacji wyrobu i nadzór nad wytwarzaniem.

\section{Literatura}

[1] PN-EN 1090-1:2010 + PN-EN 1090-1:2010/AC Wykonanie konstrukcji stalowych i aluminiowych Część 1: Zasady oceny zgodności elementów konstrukcyjnych.

[2] PN-EN 1090-2:2009 Wykonanie konstrukcji stalowych i aluminiowych Część 2: Wymagania techniczne dotyczące konstrukcji stalowych.

[3] PN-EN 1090-3:2008 Wykonanie konstrukcji stalowych i aluminiowych część 3: Wymagania techniczne dotyczące wykonania konstrukcji aluminiowych

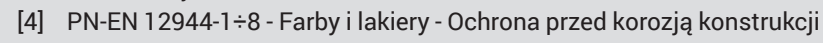
stalowych za pomocą ochronnych systemów malarskich.

[5] PN-EN 14616:2006 Natryskiwanie cieplne - Zalecenia dotyczące stosowania natryskiwania cieplnego.

[6] PN-EN 15311:2008 Natryskiwanie cieplne - Części z powłokami natryskiwanymi cieplnie - Techniczne warunki dostawy.
[7] PN-EN 14713:2010 Powłoki cynkowe - Wytyczne i zalecenia dotyczace ochrony przed korozją konstrukcji ze stopów żelaza - Część 1: Zasady ogólne dotyczące projektowania i odporności korozyjnej Powłoki cynkowe - Wytyczne i zalecenia dotyczące ochrony przed korozją konstrukcji ze stopów żelaza - Część 2: Cynkowanie zanurzeniowe.

[8] PN-EN ISO 1461:2011 Powłoki cynkowe nanoszone na wyroby stalowe i żeliwne metodą zanurzeniową - Wymagania i metody badań.

[9] PN-EN 8501-3:2008 Przygotowanie podłoży stalowych przed nakładaniem farb i podobnych produktów - Wzrokowa ocena czystości powierzchni - Część 3: Stopnie przygotowania spoin, krawędzi i innych obszarów z wadami powierzchni.

[10] PN-EN ISO 4628:2005 Farby i lakiery - Ocena zniszczenia powłok Określanie ilości i rozmiaru uszkodzeń oraz intensywności jednolitych zmian w wyglądzie. 